\title{
A duplex real-time PCR assay for the detection and quantification of avian reovirus and Mycoplasma synoviae
}

\author{
Li Huang ${ }^{1,2}$, Zhixun Xie ${ }^{1 *}$, Liji Xie ${ }^{1}$, Xianwen Deng ${ }^{1}$, Zhiqin Xie ${ }^{1}$, Sisi Luo ${ }^{1}$, Jiaoling Huang ${ }^{1}$, Tingting Zeng ${ }^{1}$ \\ and Jiaxun Feng ${ }^{2}$
}

\begin{abstract}
Background: Infectious arthritis in broilers represents an economic and health problem, resulting in severe losses due to retarded growth and downgrading at the slaughterhouse. The most common agents associated with cases of infectious arthritis in poultry are avian reovirus (ARV) and Mycoplasma synoviae (MS). The accurate differentiation and rapid diagnosis of ARV and MS are essential prerequisites for the effective control and prevention of these avian pathogens in poultry flocks. This study thus aimed to develop and validate a duplex real-time PCR assay for the simultaneous detection and quantification of ARV and MS.

Methods: Specific primers and probes for each pathogen were designed to target the special sequence of the ARV $\sigma C$ gene or the MS phase-variable surface lipoprotein hemagglutinin (VlhA) gene. A duplex real-time PCR assay was developed, and the reaction conditions were optimized for the rapid detection and quantification of ARV and MS.

Results: The duplex real-time PCR assay was capable of ARV-and MS-specific detection without cross-reaction with other non-targeted avian pathogens. The sensitivity of this assay was $2 \times 10^{1}$ copies for a recombinant plasmid containing ARV $\sigma C$ or MS VlhA gene, and 100 times higher than that of conventional PCR. This newly developed PCR assay was also reproducible and stable. All tested field samples of ARV and/or MS were detectable with this duplex real-time PCR assay compared with pathogen isolation and identification as well as serological tests.

Conclusion: This duplex real-time PCR assay is highly specific, sensitive and reproducible and thus could provide a rapid, specific and sensitive diagnostic tool for the simultaneous detection of ARV and MS in poultry flocks.

The assay will be useful not only for clinical diagnostics and disease surveillance but also for the efficient control and prevention of ARV and MS infections.
\end{abstract}

Keywords: Duplex real-time PCR assay, Avian reovirus, Mycoplasma synoviae

\section{Background}

Infectious arthritis in broilers represents an economic and health problem, resulting in severe losses due to retarded growth and downgrading at the slaughterhouse. The most common agents associated with cases of infectious arthritis in poultry are avian reovirus (ARV) and Mycoplasma synoviae (MS). ARV belongs

\footnotetext{
* Correspondence: xiezhixun@126.com

${ }^{1}$ Guangxi Key Laboratory of Animal Vaccines and New Technology, Guangxi

Veterinary Research Institute, Nanning 530001, PR China

Full list of author information is available at the end of the article
}

to the Orthoreovirus genus, one of nine genera of the Reoviridae family [1,2]. ARV infection is associated with several disease syndromes and especially viral arthritis/tenosynovitis in chickens [3,4]. Meanwhile, MS is a common pathogen found in turkeys and chickens that causes diseases of the respiratory tract, urogenital tract and joints and impairs growth [5,6]. Mixed infections of ARV and MS have occurred in poultry flocks worldwide and have similar clinical signs, includ-

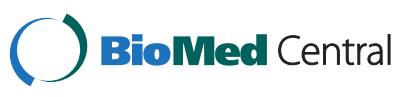

(C) 2015 Huang et al.; licensee BioMed Central. This is an Open Access article distributed under the terms of the Creative Commons Attribution License (http://creativecommons.org/licenses/by/4.0), which permits unrestricted use, distribution, and reproduction in any medium, provided the original work is properly credited. The Creative Commons Public Domain Dedication waiver (http://creativecommons.org/publicdomain/zero/1.0/) applies to the data made available in this article, unless otherwise stated. 
Table 1 Specific primers used to clone ARV and MS specific genes

\begin{tabular}{|c|c|c|c|}
\hline Primer name & Primer sequence & Amplicon length & Target gene \\
\hline ARV C703F & 5'-TGTGGATCCATGGCGGGTCTCAAT-3' & $981 \mathrm{bp}$ & $\sigma C$ gene \\
\hline ARV C703R & 5'-CCGGAATTCTAAGGTGTCGATGCC-3' & & \\
\hline MS vlhA F2 & 5'-CTGTTATAGCAATTTCATGTGGTG-3' & $283 \mathrm{bp}$ & phase-variable surface lipoprotein hemagglutinin (vlhA) \\
\hline MS vlhA R2 & 5'-TGTTGTAGTTGCTTCAACTTGTCT-3' & & \\
\hline
\end{tabular}

ing severe immunosuppression, arthritis, depression, retarded growth, weight loss and decreased egg production. Bradbury [7] and Reck [8] also found that in chickens, a synergistic relationship exists between ARV and MS, which causes much more severe clinical signs and pathological lesions than the additive effects of these two pathogens alone do. The main feature of possible economic importance in ARV and MS infection is the incidence of decreased egg production and fertility, sternal bursitis leading to carcass downgrading and leg abnormalities related to condemnation of broilers. As the elimination of lesioned carcasses at the slaughterhouse is important [3,9], the rapid and efficient detection and diagnosis of ARV and MS are essential prerequisites for the effective control and prevention of these avian pathogens in poultry flocks.

The current methods for ARV and MS detection include serological assays; pathogen isolation and identification; and molecular detection methods, such as single PCR and multiplex PCR [10-13]. However, these assays are laborious and time consuming, have limited specificity and sensitivity, and require postamplification procedures. Real-time PCR assays for the specific identification of a target sequence by fluorescent probes can overcome these limitations and provide distinct advantages, such as a shorter detection time, improved sensitivity and specificity, simplified closed-tube procedures and the potential for pathogen screening and surveillance in commercial poultry flocks [14-16].

Therefore, the present study developed and validated a duplex real-time PCR assay for the differential diagnosis and quantitative detection of ARV and MS.

\section{Materials and methods}

\section{Ethics statement}

This study was performed in strict accordance with the recommendations in the Guide for the Care and Use of Laboratory Animals of the Guangxi Veterinary Research Institute. Additionally, the Animal Care and Use Committee of the Guangxi Veterinary Research Institute approved all procedures involving the use of animals, and all efforts were made to minimize animal suffering.

\section{Pathogens and construction of recombinant plasmids}

DNA was first extracted from MS samples as described previously [17], and total RNA was extracted from ARV samples using TRIzol reagent (Life Technologies, Carlsbad, CA, USA) following the manufacturer's instructions. Next, cDNA was generated as described previously [18] and used as a template for a duplex real-time PCR assay. Target gene fragments from the ARV $\sigma \mathrm{C}$ gene or the MS phase-variable surface lipoprotein hemagglutinin (vlhA) gene were then amplified with the primers listed in Table 1 and inserted into the pMD18-T vector (TaKaRa, Dalian, China). Subsequently, the constructed plasmids were transformed into DH5 $\alpha$ Escherichia coli. The recombinant plasmids carrying each target gene were confirmed by sequencing and were used as positive standards for ARV and MS. The copy number of each positive-standard plasmid was calculated as described previously [19].

\section{Oligonucleotide primers and DNA probes for duplex} real-time PCR

DNASTAR software (DNASTAR Inc., Madison, WI, USA) was used to confirm the highly conserved regions in the ARV and MS genomes, and Primer Express 3.0

Table 2 Primers and probes used for the duplex real-time PCR assay

\begin{tabular}{llll}
\hline Primer/probe name & Primer/probe sequence & Target gene & Amplicon length \\
\hline ARV F & 5'-CGTTCCCTGTGGACGTATCA-3' & oC & \\
ARV R & 5'-GAGTACACCCCATACGCTTGGT-3' & \\
ARV P & 5'-(FAM) TCACCCGCGATTCTGCGACTCAT (Eclipse)-3' & \\
MS-F & 5'-ATAGCAATTCATGTGGTGATCAA-3' & vlhA \\
MS-R & 5'-TGGATTGGGTTTTGAGGATTA-3' & \\
MS-P & 5'-(ROX) CAGCACCTGAACCAACACCTGGAA (Eclipse)-3' & \\
\hline
\end{tabular}



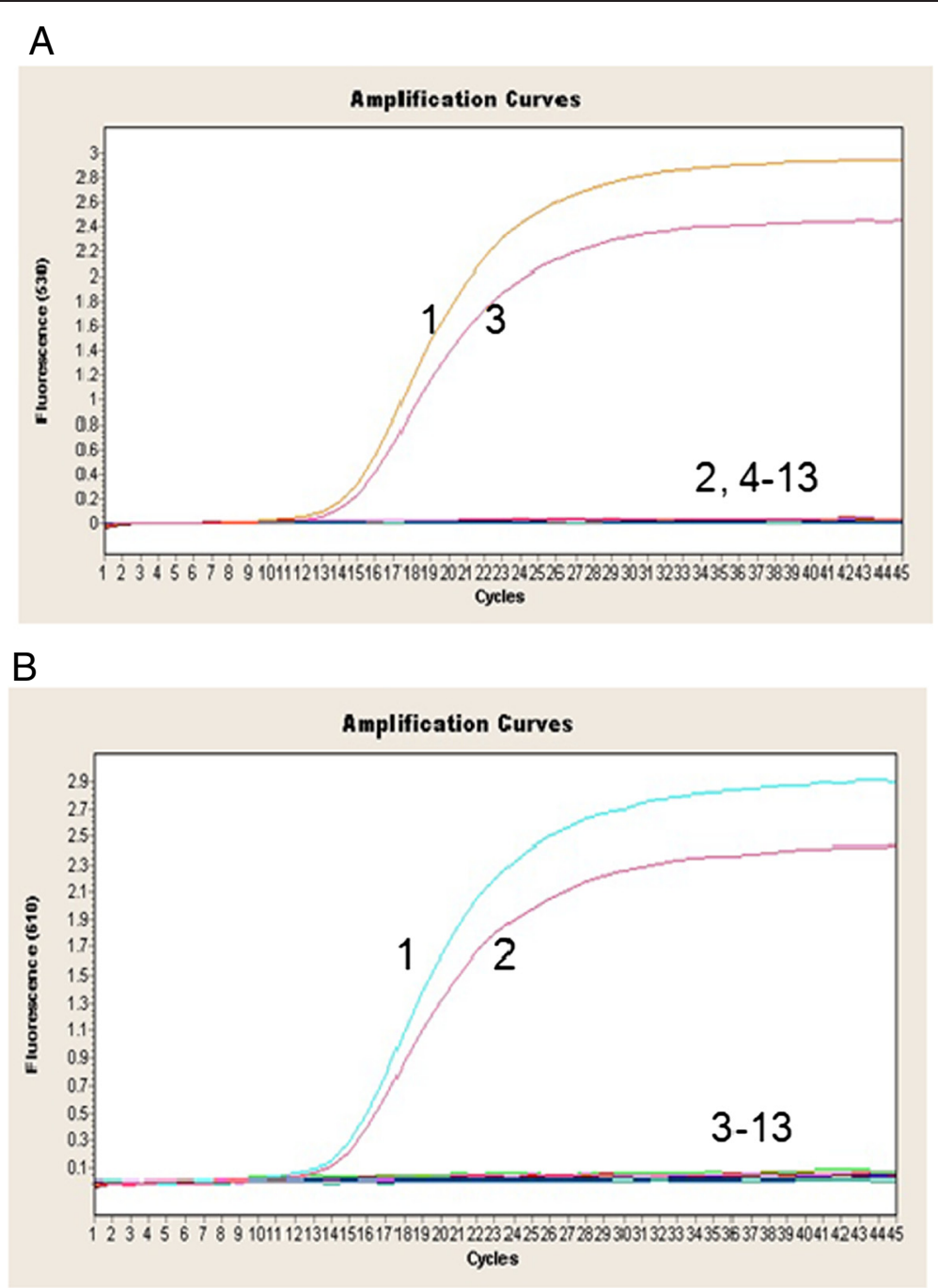

Figure 1 Specificity of the duplex real-time PCR assay for ARV and MS. (A) Specificity of the duplex real-time PCR assay for ARV. 1. MS + ARV, 2. MS, 3. ARV, 4. IBDV, 5. NDV, 6. AIBV, 7. MDV, 8. H9 subtype of AIV, 9. REV, 10. ALV, 11. MG, 12. MI, 13. MM, 14. negative control. (B) Specificity of the duplex real-time PCR assay for MS. 1. MS + ARV, 2. MS, 3. ARV, 4. IBDV, 5. NDV, 6. AlBV, 7. MDV, 8. H9 subtype of AIV, 9. REV, 10. ALV, 11. MG, 12. MI, 13. MM, 14. negative control.

software (Applied Biosystems, Foster City, CA, USA) was used to design the primers and probes listed in Table 2 for ARV and MS, based on their highly conserved regions. The cross-reactivity of the oligonucleotides was assessed by BLAST analysis. Both sets of primers and probes were synthesized by TaKaRa (Dalian, China).

\section{Duplex real-time PCR assay for simultaneous MS and ARV detection}

The duplex real-time PCR was performed in a $20-\mu \mathrm{l}$ volume. The reaction mixture included $1 \times$ real-time PCR Premix (Perfect Real Time PCR Kit, TaKaRa, Dalian, China); $0.3 \mu \mathrm{M}$ ARV F, ARV R and ARV P primers; $0.3 \mu \mathrm{M}$ MS F, MS R and MS P primers; and $2 \mu \mathrm{l}$ of positive-plasmid template. Sterilized $\mathrm{H}_{2} \mathrm{O}$ was added to bring the final volume to $20 \mu \mathrm{l}$. The protocol for the reaction was $95^{\circ} \mathrm{C}$ for $30 \mathrm{sec} ; 45$ cycles of $95^{\circ} \mathrm{C}$ for $10 \mathrm{sec}$ and $60^{\circ} \mathrm{C}$ for $30 \mathrm{sec}$; and, finally, $40^{\circ} \mathrm{C}$ for $5 \mathrm{sec}$. The fluorescence was measured at the end of each $60^{\circ} \mathrm{C}$ incubation. The data analysis was performed using Light Cycler 2.0 system software (Roche, Molecular Biochemical, Mannheim, Germany).

\section{Conventional RT-PCR and PCR}

Conventional RT-PCR for ARV amplification and conventional PCR for MS amplification were performed. The PCR mixture contained $2 \times$ Premix Taq (TaKaRa, 
Dalian, China), $0.4 \mu \mathrm{M}$ forward primer or reverse primer, $2 \mu \mathrm{l}$ of template and sterilized $\mathrm{H}_{2} \mathrm{O}$ to bring the final reaction volume to $25 \mu \mathrm{l}$. The conditions for PCR were $95^{\circ} \mathrm{C}$ for $5 \mathrm{~min} ; 72^{\circ} \mathrm{C}$ for $7 \mathrm{~min}$; and three-step cycling 35 times at $95^{\circ} \mathrm{C}$ for $30 \mathrm{sec}, 60^{\circ} \mathrm{C}$ for $30 \mathrm{sec}$ and $72^{\circ} \mathrm{C}$ for $30 \mathrm{sec}$. The PCR product was run on a $2 \%$ agarose gel at $80 \mathrm{~V}$ for $45 \mathrm{~min}$ and visualized on a molecular imager Gel Doc XR+ imaging system with Image Lab software (Bio-Rad, Life Science Research, Hercules, CA, USA).

\section{Specificity and sensitivity of the duplex real-time PCR assay}

To assess the specificity of the assay, DNA from Mycoplasma gallisepticum (MG), Mycoplasma iowae (MI) and Mycoplasma meleagridis (MM) were extracted as described previously [17]. Additionally, cDNA was generated from total RNA that was extracted from cases of newcastle disease virus (NDV), infectious bursal disease virus (IBDV), avian infectious bronchitis virus (AIBV), the $\mathrm{H} 9$ subtype of the avian influenza virus (AIV), Marek's disease virus (MDV), reticuloendotheliosis virus (REV), and avian leukosis virus (ALV) using TRIzol reagent (Life Technologies, Carlsbad, CA, USA) following the manufacturer's instructions. The DNA and cDNA were mixed together in equal concentrations as the templates and were subjected to the optimized duplex real-time PCR assay to detect ARV and MS. The sensitivity of the duplex real-time PCR assay was determined using serial 10 -fold dilutions $\left(10^{1}-10^{8}\right.$ copies $/ \mu \mathrm{l})$ of positive-plasmid combinations carrying the MS and ARV target genes as templates. These results were compared with the results of conventional PCR. To generate a standard curve for ARV and MS, the threshold cycle $(\mathrm{Ct})$ of these standard dilutions was plotted against the log value of the copy number of the corresponding standard plasmid.

\section{Reproducibility and interference tests of the duplex real-time PCR assay}

To assess the intra- and inter-assay reproducibility, three samples with the same concentration $\left(10^{8}\right.$ cop$\mathrm{ies} / \mu \mathrm{l})$ of the MS or ARV target gene were assessed using the duplex real-time PCR assay. The same experiments were repeated in triplicate every two days for seven days. The reproducibility was then analyzed based on the standard deviation (SD) and the coefficient of variability $(\mathrm{CV})$ of the $\mathrm{Ct}$ average. To determine the reaction efficiency interference, different concentrations of positive plasmids carrying the ARV or MS target gene $\left(10^{8}\right.$ and $10^{1}$ copies/ $\mu$, respectively) were analyzed using the duplex real-time PCR assay.
Table 3 Pathogens used and Ct values of the duplex real-time PCR assay's specificity

\begin{tabular}{llll}
\hline Pathogen & $\begin{array}{l}\text { Number of } \\
\text { samples }\end{array}$ & $\begin{array}{l}\text { Ct values of duplex } \\
\text { real-time PCR assay }\end{array}$ \\
\cline { 2 - 4 } & 1 & MS & ARV \\
\hline NDV & 1 & Negative & Negative \\
H9 subtype of AIV & 1 & Negative & Negative \\
IBDV & 1 & Negative & Negative \\
MG & 1 & Negative & Negative \\
MM & 1 & Negative & Negative \\
MI & 1 & Negative & Negative \\
MDV & 1 & Negative & Negative \\
PMD18-T-ARV & 1 & Negative & 15.58 \\
PMD18-T-MS & 1 & 15.31 & Negative \\
REV & 1 & Negative & Negative \\
ALV & 1 & Negative & Negative \\
\hline
\end{tabular}

\section{Duplex real-time PCR analysis of field samples}

All field samples, such as joints and joint contents, were collected from chicks and broilers exhibiting clinical signs of MS or ARV infections and were used to validate the duplex real-time PCR assay. The results were compared with those of traditional diagnostic methods, such as pathogen isolation and identification and serological tests.

\section{Results}

\section{Specificity test}

The specificity of the duplex real-time PCR assay was verified by examining DNA/cDNA from different samples infected with different pathogens. As shown in Figure 1 and Table 3, the duplex real-time PCR assay was able to detect and differentiate ARV and MS independently and simultaneously. In contrast, the other avian pathogens (NDV, IBDV, AIBV, AIV, MDV, REV, ALV, MG, MI and MM) were not detected using the duplex real-time PCR assay. When samples were coinfected with both ARV and MS, unique amplification curves were simultaneously produced in the $530 \mathrm{~nm}$ and $610 \mathrm{~nm}$ channels, whereas a single amplification curve was observed in the $530 \mathrm{~nm}$ or $610 \mathrm{~nm}$ channel when samples were infected with only ARV or MS, respectively. Thus, the specificity of the duplex real-time PCR assay was $100 \%$, with no detectable fluorescent signals for other avian pathogens or negative controls.

\section{Sensitivity test}

The sensitivity of the duplex real-time PCR assay was verified by testing $10^{1}-10^{8}$ copies/ $\mu \mathrm{l}$ of recombinant 


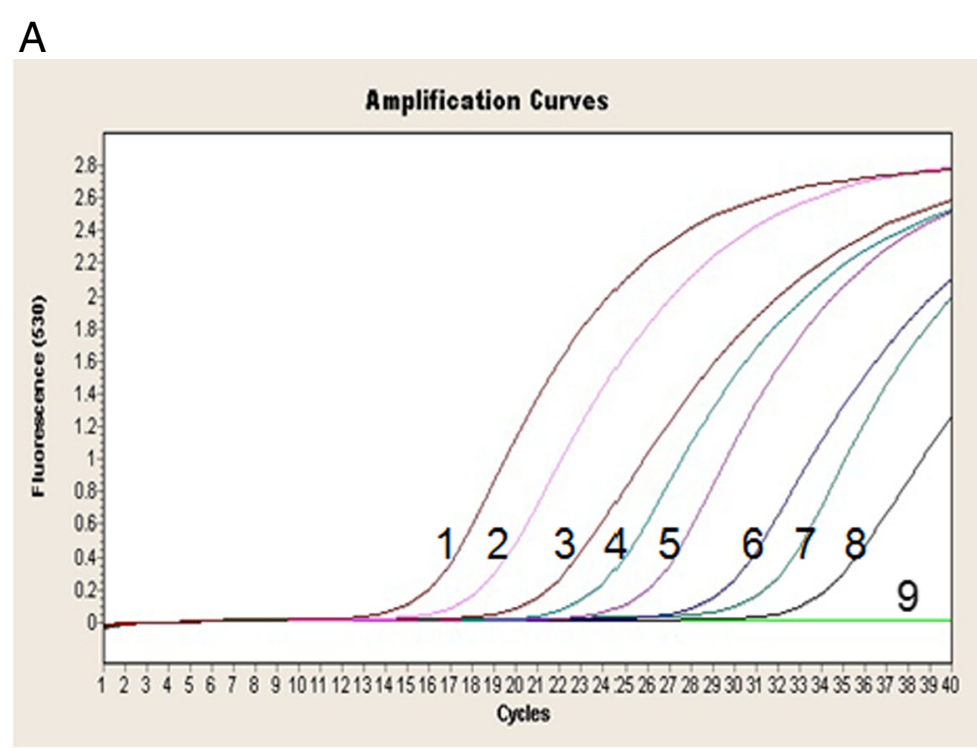

B

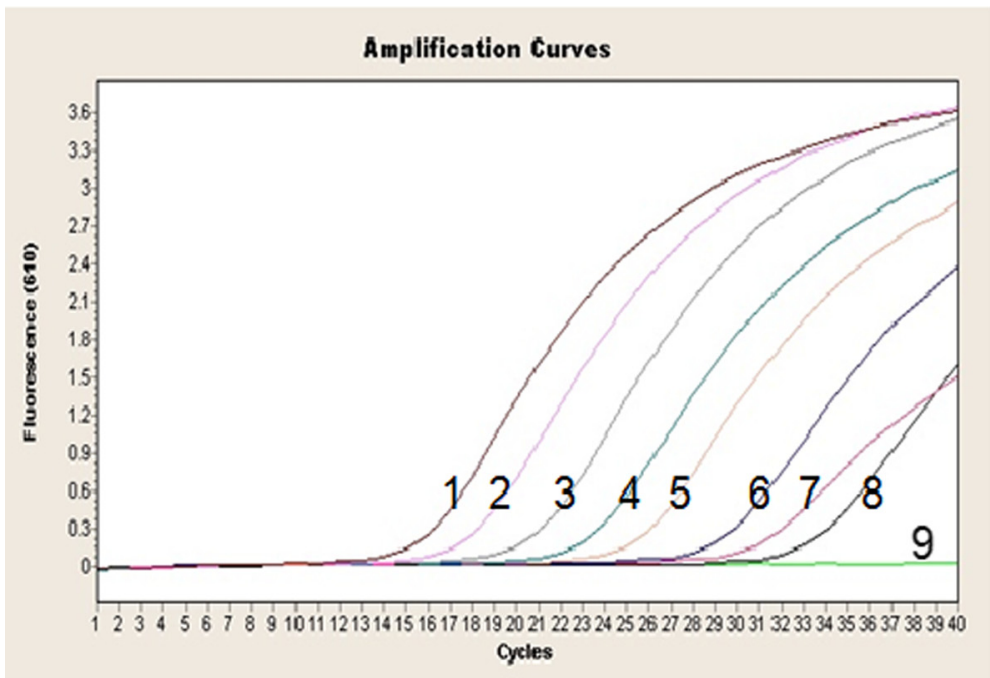

Figure 2 Sensitivity of the duplex real-time PCR assay for ARV and MS. (A) Sensitivity of the duplex real-time PCR assay for ARV. 1.2 $2 \times 10^{8}$ copies, $2.2 \times 10^{7}$ copies, $3.2 \times 10^{6}$ copies, $4.2 \times 10^{5}$ copies, $5.2 \times 10^{4}$ copies, $6.2 \times 10^{3}$ copies, $7.2 \times 10^{2}$ copies, $8.2 \times 10^{1}$ copies, 9 . negative control. (B) Sensitivity of the duplex real-time PCR assay for MS. 1. $2 \times 10^{8}$ copies, $2.2 \times 10^{7}$ copies, $3.2 \times 10^{6}$ copies, $4.2 \times 10^{5}$ copies, $5.2 \times 10^{4}$ copies, $6.2 \times 10^{3}$ copies, $7.2 \times 10^{2}$ copies, $8.2 \times 10^{1}$ copies, 9 . negative control.

plasmids carrying the ARV or MS target gene. In Figure 2, the ARV amplification curves are shown in the $530 \mathrm{~nm}$ channel (Figure 2A), and the MS amplification curves are shown in the $610 \mathrm{~nm}$ channel (Figure 2B). Moreover, the standard curves for ARV and MS are shown in Figure 3, and the Ct values are listed in Table 4. The results revealed that even with a template amount as low as $2 \times 10^{1}$ copies, the ARV or MS target gene was still detectable. In contrast, the detection limit of the conventional PCR template was $2 \times 10^{3}$ copies for ARV and MS (Figure 4), which is 100 times lower than that of the duplex real-time PCR assay. Thus, the duplex real-time PCR assay is highly sensitive.

\section{Reproducibility and interference tests}

The reaction of reproducibility was determined by testing three samples of the same concentration at the same time points and was assessed using the SD and CV of the $\mathrm{Ct}$ values for each sample. The intra-assay reproducibility results are shown in Figure 5, and the inter-assay reproducibility results are listed in Table 5. The CV values were $1.61 \%$ for ARV and $1.89 \%$ for MS. These 


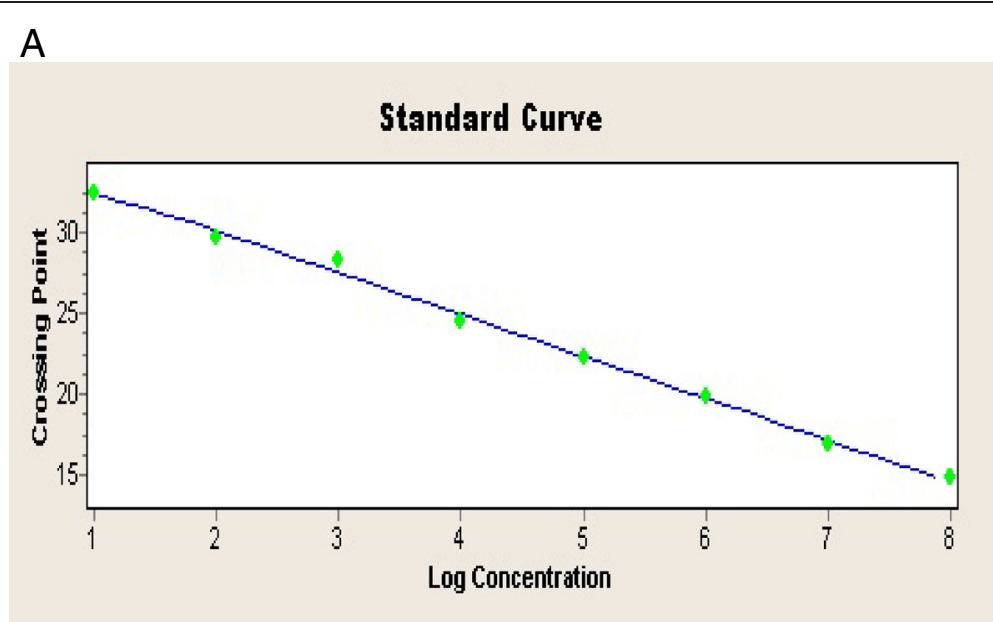

B

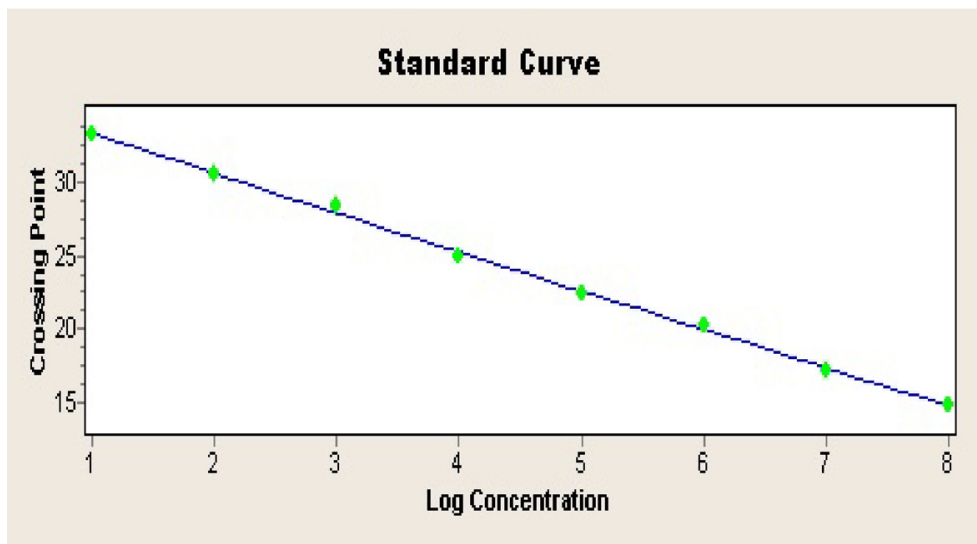

Figure 3 ARV and MS standard curves. (A) ARV standard curve. (B) MS standard curve.

data indicate that the findings produced by the duplex real-time PCR assay are reproducible.

Because the presence of other templates may affect the amplification efficiency of a PCR assay, we tested the influence of mixtures of different concentrations on reaction sensitivity. In particular, a combination of a high concentration $\left(10^{8}\right.$ copies $\left./ \mu \mathrm{l}\right)$ and a low concentration $\left(10^{2}\right.$ copies/ $\left.\mu \mathrm{l}\right)$ of positive plasmids carrying the ARV or MS target gene was used in an interference test (Table 6). The results indicated that there were no systematic deviations in the amplification curves of the mixed templates compared with those of the single template; moreover, the CV value was less than 3\% (data not shown). The results suggest that the newly developed duplex realtime PCR assay is stable.

\section{Field samples}

The detection results of the duplex real-time PCR assay for 40 field samples are listed in Table 7 and the results were confirmed by pathogen isolation and identification or serological tests. The ARV detection rate was $7.5 \%$, and the MS detection rate was 5\%. Additionally, the range of $\mathrm{Ct}$ values for ARV was 15.29-34.42, and the range of $\mathrm{Ct}$ values for MS was 13.53-30.68. Thus, the results of this new assay were comparable with the results of other detection approaches.

Table $4 \mathrm{Ct}$ values from the serial dilution of positive plasmids

\begin{tabular}{|c|c|c|c|c|c|c|c|c|}
\hline Tenfold dilution & $\begin{array}{l}2 \times 10^{8} \\
\text { copies }\end{array}$ & $\begin{array}{l}2 \times 10^{7} \\
\text { copies }\end{array}$ & $\begin{array}{l}2 \times 10^{6} \\
\text { copies }\end{array}$ & $\begin{array}{l}2 \times 10^{5} \\
\text { copies }\end{array}$ & $\begin{array}{l}2 \times 10^{4} \\
\text { copies }\end{array}$ & $\begin{array}{l}2 \times 10^{3} \\
\text { copies }\end{array}$ & $\begin{array}{l}2 \times 10^{2} \\
\text { copies }\end{array}$ & $\begin{array}{l}2 \times 10^{1} \\
\text { copies }\end{array}$ \\
\hline $\mathrm{ARV}(\mathrm{Ct})$ & 14.86 & 17.21 & 20.2 & 22.49 & 24.9 & 28.36 & 30.45 & 33.18 \\
\hline $\mathrm{MS}(\mathrm{Ct})$ & 14.79 & 16.83 & 19.77 & 22.18 & 24.49 & 28.24 & 29.72 & 32.41 \\
\hline
\end{tabular}




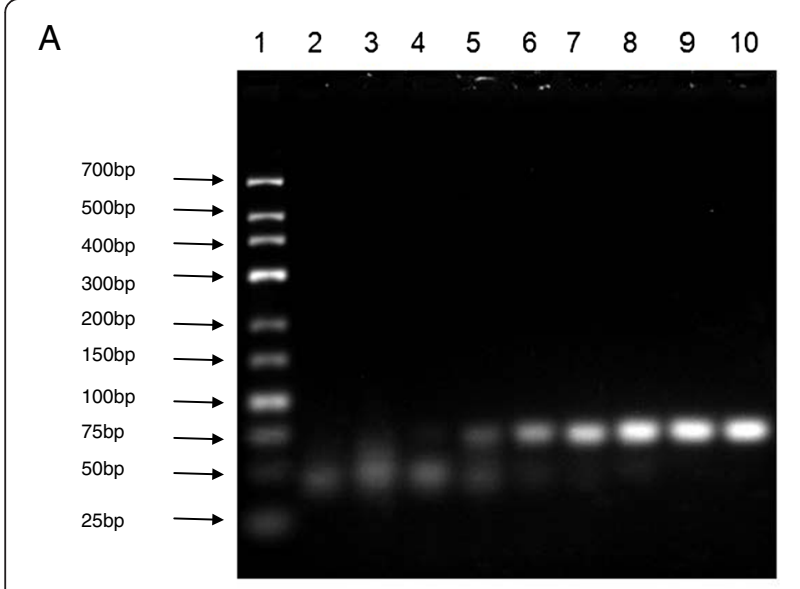

B

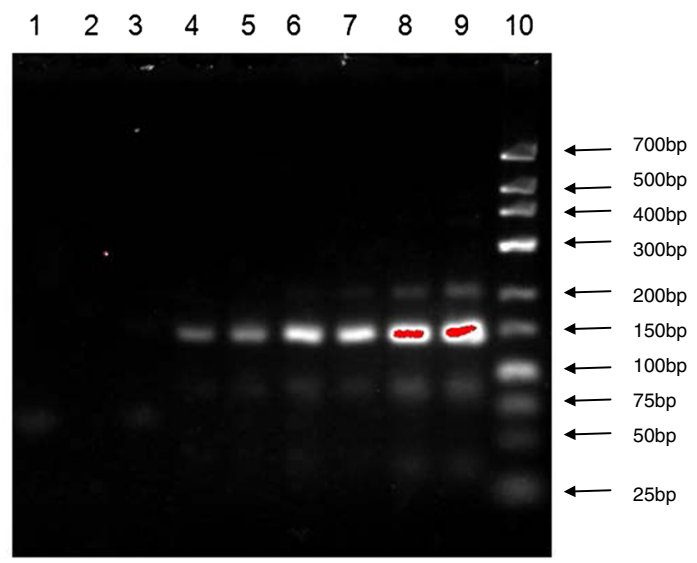

Figure 4 Sensitivity of conventional PCR for ARV and MS. (A) Sensitivity of conventional PCR for ARV. 1. low ladder, 2. negative control, $3.2 \times 10^{1}$ copies, $4.2 \times 10^{2}$ copies, $5.2 \times 10^{3}$ copies, $6.2 \times$ $10^{4}$ copies, $7.2 \times 10^{5}$ copies, $8.2 \times 10^{6}$ copies, $9.2 \times 10^{7}$ copies, 10 . $2 \times 10^{8}$ copies. (B) Sensitivity of conventional PCR for MS. 1. negative control, $2.2 \times 10^{1}$ copies, $3.2 \times 10^{2}$ copies, $4.2 \times 10^{3}$ copies, $5.2 \times$ $10^{4}$ copies, $6.2 \times 10^{5}$ copies, $7.2 \times 10^{6}$ copies, $8.2 \times 10^{7}$ copies, 9 . $2 \times 10^{8}$ copies, 10 . low ladder.

\section{Discussion}

Both MS and ARV can cause similar clinical signs and lesions and may be present as co-infections in chickens and other avian species, which can lead to huge economic losses [20]. In this paper, we developed a duplex real-time PCR assay and described its use for the rapid, sensitive and accurate quantitative detection of ARV and MS.

The primary advantage of this duplex real-time PCR assay is the simultaneous detection and differentiation of ARV and MS. By using unique primer and probe sets within the highly conserved gene regions of ARV and MS, this duplex real-time PCR assay is readily able to detect and differentiate these pathogens via one reaction. Furthermore, this assay is optional and can be utilized as a single-target assay or combined into duplex assays, without impacting the quality of the results. Specifically, duplexing reduces the expense of reagents and the required time for analysis, and the singletarget assay makes this assay adaptable to circumstances that may not require the simultaneous detection of these two pathogens for diagnostic purposes. These advantages greatly facilitate clinical application, which is an important criterion for the usefulness of a diagnostic assay for the early surveillance and prevention of diseases [21].

For a method of pathogen detection to be used as a clinical diagnostic tool, sensitivity is a key criterion $[22,23]$. Using the newly developed assay, as few as $2 \mathrm{x}$ $10^{1}$ copies could be detected for both ARV and MS, which was more sensitive than the results of a duplex real-time PCR assay reported by Sprygin [24] and the results of the multiplex PCR performed by Reck [11]. Moreover, during detection with mixed samples (other non-targeted pathogens) and field samples, the specificity of this new assay was comparable with that of traditional methods, such as pathogen isolation and identification and serological tests. Therefore, this duplex real-time PCR assay with higher sensitivity rates could be promising as a tool for rapid clinical differentiation and diagnosis at the early stage of ARV and/or MS infection.

Another distinct feature of this duplex real-time PCR assay is the short turn-around time for the results. In the present study, the results for ARV and MS infections were obtained within $2 \mathrm{~h}$ with this duplex realtime PCR assay, which is very important for rapid diagnosis, especially during emergent disease outbreaks. Furthermore, the obtained results could be directly visualized on a computer connected to the real-time PCR station. Compared with the conventional diagnostic approaches for ARV and MS infections (and even single and multiplex PCRs $[25,26])$, this assay does not require additional unique equipment or specialized labor. This method also minimizes post-amplification procedures, such as electrophoresis and UV visualization, which are time consuming. As compared to recently developed isothermal methods for ARV or MS detection, including loop-mediated isothermal amplification $[27,28]$ and cross-priming amplification [29], for which there is no need for expensive equipment except a water bath, the main drawback of the duplex real-time PCR assay is the absolute need for the thermal cycle. However, the method capability of simultaneous detection for ARV and MS highlights its importance and great value for the rapid detection of ARV and MS infections in the laboratory. 
A

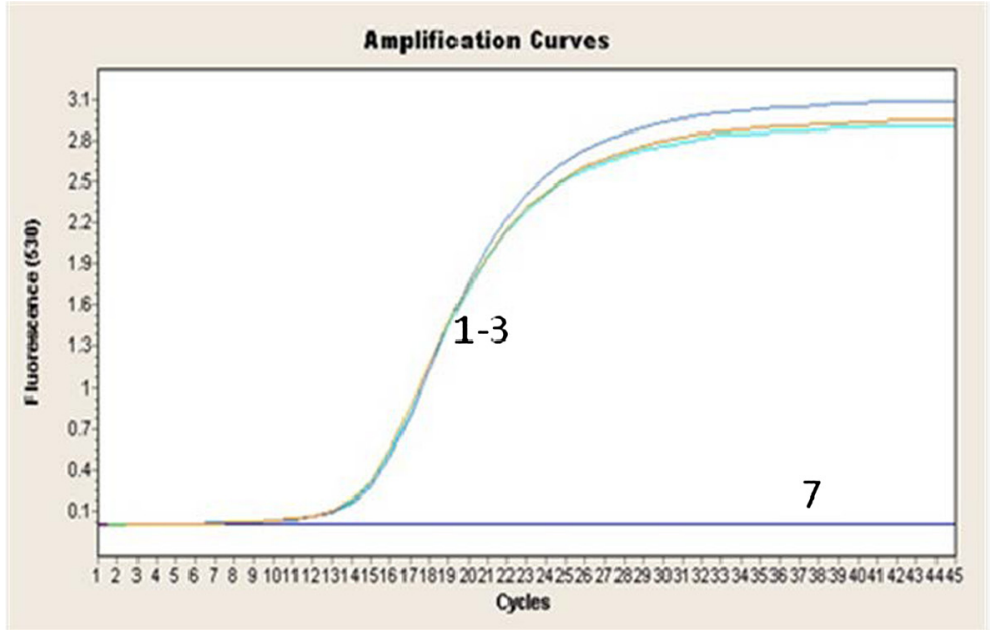

B

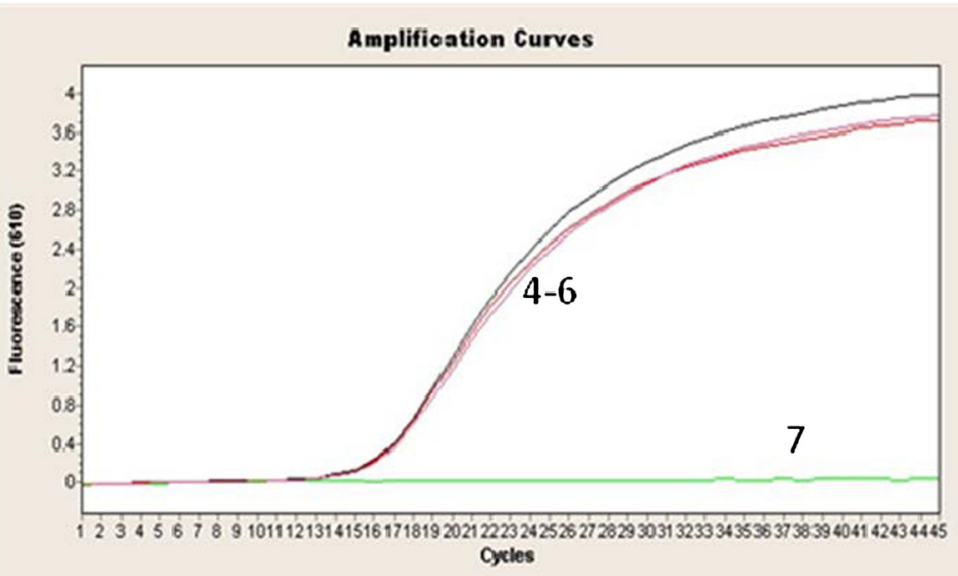

Figure 5 Reproducibility of the duplex real-time PCR assay for ARV (A) and MS (B). 1-3. ARV, 4-6. MS, 7. negative control.

Table 5 Reproducibility of the duplex real-time PCR assay for ARV and MS

\begin{tabular}{llllll}
\hline Pathogen & \multicolumn{4}{l}{ Ct values of same samples at different time points } \\
\cline { 2 - 6 } & Day $\mathbf{1}$ & Day $\mathbf{4}$ & Day $\mathbf{7}$ & SD & CV \\
\hline ARV & $15.23 / 1 \times 10^{8}$ & $15.4 / 1 \times 10^{8}$ & $15.36 / 1 \times 10^{8}$ & 0.24 & $1.61 \%$ \\
MS & $14.96 / 1 \times 10^{8}$ & $14.7 / 1 \times 10^{8}$ & $15.09 / 1 \times 10^{8}$ & 0.28 & $1.89 \%$ \\
\hline
\end{tabular}

Table 6 Samples used in the interference test

\begin{tabular}{lllllll}
\hline Pathogen & Sample $\mathbf{1}$ & Sample $\mathbf{2}$ & Sample $\mathbf{3}$ & Sample $\mathbf{4}$ & Sample $\mathbf{5}$ & Sample $\mathbf{6}$ \\
\hline ARV & $2 \times 10^{8}$ copies & $2 \times 10^{2}$ copies & $2 \times 10^{8}$ copies & - & $2 \times 10^{2}$ copies & - \\
MS & $2 \times 10^{2}$ copies & $2 \times 10^{8}$ copies & - & $2 \times 10^{8}$ copies & - & $2 \times 10^{2}$ copies \\
\hline
\end{tabular}

Table 7 Detection of field samples using the duplex real-time PCR assay

\begin{tabular}{lll}
\hline & ARV & MS \\
\hline Positive samples/total samples & $3 / 40$ & $2 / 40$ \\
Positive rate & $7.5 \%$ & $5 \%$ \\
\hline
\end{tabular}


Considering the high cost of probe synthesis and the possibility of different genotypes as well as variant or vaccine strains of ARV or MS, the development of new technology or novel reagents for probe synthesis and the design of more primers based on more highly conserved regions of the ARV and MS genomes would be necessary to investigate further modification and optimization of this new assay.

\section{Conclusion}

In this study, we developed a rapid, specific and sensitive duplex real-time PCR assay for the simultaneous detection of ARV and MS. Based on its speed and sensitivity, this newly developed assay could be useful not only for the clinical diagnosis of ARV and MS infections but also for the control and prevention of these infections.

\section{Competing interests}

The authors declare that they have no competing interests.

\section{Authors' contributions}

$\mathrm{LH}$ and $Z X$ designed the experiments. $L X, X D, Z X, S L, T Z$ and JF prepared the RNA/DNA samples. LH designed the primers and optimized the conditions of the duplex real-time PCR assay. LH, LX, XD, ZX, SL and TZ carried out the experiments shown in Figures 1, 2, 3, 4 and 5 and in Tables 3, 4, 5 and 7. LH performed the data analysis. LH wrote the manuscript. All authors reviewed and approved the final version of the manuscript.

\section{Acknowledgments}

This study was supported by the National Natural Science Foundation of China (31160512), China Postdoctoral Science Foundation (2014M552536XB), Guangxi Science and Technology Projects (1222003-2-4,

2013GXNSFBA019120 and 2014GXNSFCA118006), and Guangxi Government Senior Scientist Foundation (2011B020) (Guangxi, China).

\section{Author details}

${ }^{1}$ Guangxi Key Laboratory of Animal Vaccines and New Technology, Guangxi Veterinary Research Institute, Nanning 530001, PR China. ${ }^{2}$ College of Life Science and Technology, Guangxi University, Nanning 530004, PR China.

Received: 21 October 2014 Accepted: 31 January 2015

Published online: 12 February 2015

\section{References}

1. Teng L, Xie Z, Xie L, Liu J, Pang Y, Deng X, et al. Complete genome sequences of an avian orthoreovirus isolated from guangxi, china. Genome Announc. 2013;1(4):e00495-13.

2. Teng $L$, Xie Z, Xie L, Liu J, Pang Y, Deng X, et al. Sequencing and phylogenetic analysis of an avian reovirus genome. Virus Genes. 2014;48:381-6.

3. Jones RC. Avian reovirus infections. Rev Sci Tech. 2000;19:614-25.

4. van der Heide L. The history of avian reovirus. Avian Dis. 2000;44:638-41.

5. Lockaby SB, Hoerr FJ, Lauerman LH, Kleven SH. Pathogenicity of Mycoplasma synoviae in broiler chickens. Vet Pathol. 1998;35:178-90.

6. Hinz KH, Blome C, Ryll M. Virulence of Mycoplasma synoviae strains in experimentally infected broiler chickens. Berl Munch Tierarztl Wochenschr. 2003;116:59-66.

7. Bradbury JM, Garuti A. Dual infection with Mycoplasma synoviae and a tenosynovitis-inducing reovirus in chickens. Avian Pathogy. 1978;7(3):407-19.

8. Reck C, Menin ÁM, Pilati C, Milettia LC. Clinical and histologic lesions of mixed infection with Avian orthoreovirus and Mycoplasma synoviae in broilers. Pesqui Vet Bras. 2012;32:687-91.

9. Landman WJ, Feberwee A. Aerosol-induced Mycoplasma synoviae arthritis: the synergistic effect of infectious bronchitis virus infection. Avian Pathol. 2004;33:591-8.
10. Ortiz A, Kleven SH. Serological detection of Mycoplasma synoviae infection in turkeys. Avian Dis. 1992:36:749-52.

11. Reck C, Menin A, Canever MF, Milettia LC. Rapid detection of Mycoplasma synoviae and avian reovirus in clinical samples of poultry using multiplex PCR. Avian Dis. 2013;57:220-4.

12. Noormohammadi AH, Markham PF, Markham JF, Whithear KG, Browning GF. Mycoplasma synoviae surface protein MSPB as a recombinant antigen in an indirect ELISA. Microbiology. 1999;145(Pt 8):2087-94.

13. Ben Abdelmoumen Mardassi B, Ben Mohamed R, Gueriri I, Boughattas S, Mlik B. Duplex PCR to differentiate between Mycoplasma synoviae and Mycoplasma gallisepticum on the basis of conserved species-specific sequences of their hemagglutinin genes. J Clin Microbiol. 2005;43:948-58.

14. Troxler S, Marek A, Prokofieva I, Bilic I, Hess M. TaqMan real-time reverse transcription-PCR assay for universal detection and quantification of avian hepatitis $E$ virus from clinical samples in the presence of a heterologous internal control RNA. J Clin Microbiol. 2011;49:1339-46.

15. Wittwer CT, Herrmann MG, Gundry CN, Elenitoba-Johnson KS. Real-time multiplex PCR assays. Methods. 2001;25:430-42.

16. Mackay IM, Arden KE, Nitsche A. Real-time PCR in virology. Nucleic Acids Res. 2002;30:1292-305.

17. Xie Z, Luo S, Xie L, Liu J, Pang Y, Deng $X$, et al. Simultaneous typing of nine avian respiratory pathogens using a novel GeXP analyzer-based multiplex PCR assay. J Virol Methods. 2014;207:188-95.

18. Xie Z, Xie L, Pang Y, Lu Z, Xie Z, Sun J, et al. Development of a real-time multiplex PCR assay for detection of viral pathogens of penaeid shrimp. Arch Virol. 2008;153:2245-51.

19. Vaitomaa J, Rantala A, Halinen K, Rouhiainen L, Tallberg P, Mokelke L, et al. Quantitative real-time PCR for determination of microcystin synthetase e copy numbers for microcystis and anabaena in lakes. Appl Environ Microbiol. 2003;69:7289-97.

20. Montebugnoli L, Venturi M, Gissi DB, Cervellati F. Clinical and histologic healing of lichenoid oral lesions following amalgam removal: a prospective study. Oral Surg Oral Med Oral Pathol Oral Radiol. 2012;113:766-72.

21. Heidenreich A, Bellmunt J, Bolla M, Joniau S, Mason M, Matveev V, et al. EAU guidelines on prostate cancer. Part 1: screening, diagnosis, and treatment of clinically localised disease. Eur Urol. 2011;59:61-71.

22. Heidenreich A, Bellmunt J, Bolla M, Joniau S, Mason M, Matveev V, et al. EAU guidelines on prostate cancer. Part I: screening, diagnosis, and treatment of clinically localised disease. Actas Urol Esp. 2011;35:501-14.

23. Wu H, Rao P, Jiang Y, Opriessnig T, Yang Z. A sensitive multiplex real-time $P C R$ panel for rapid diagnosis of viruses associated with porcine respiratory and reproductive disorders. Mol Cell Probes. 2014;28(5-6):264-70.

24. Sprygin AV, Andreychuk DB, Kolotilov AN, Volkov MS, Runina IA, Mudrak NS, et al. Development of a duplex real-time TagMan PCR assay with an internal control for the detection of Mycoplasma gallisepticum and Mycoplasma synoviae in clinical samples from commercial and backyard poultry. Avian Pathol. 2010;39:99-109.

25. Jindal N, Chander Y, Patnayak DP, Mor SK, Ziegler AF, Goyal SM. A multiplex RT-PCR for the detection of astrovirus, rotavirus, and reovirus in turkeys. Avian Dis. 2012;56:592-6.

26. Xie Z, Fadl AA, Girshick T, Khan MI. Amplification of avian reovirus RNA using the reverse transcriptase-polymerase chain reaction. Avian Dis. 1997:41:654-60.

27. Kursa O, Wozniakowski G, Tomczyk G, Sawicka A, Minta Z. Rapid detection of Mycoplasma synoviae by loop-mediated isothermal amplification. Arch Microbiol 2014. doi:10.1007/s00203-014-1063-2

28. Xie Z, Peng Y, Luo S, Wang Y, Liu J, Pang Y, et al. Development of a reverse transcription loop-mediated isothermal amplification assay for visual detection of avian reovirus. Avian Pathol. 2012:41:311-6.

29. Wozniakowski G, Niczyporuk JS, Samorek-Salamonowicz E, Gawel A. The development and evaluation of cross-priming amplification (CPA) for the detection of avian reovirus (ARV). J Appl Microbiol 2014. doi:10.1111/jam.12705. 